\title{
General Transcription Factor IIH Subunit 2
}

National Cancer Institute

\section{Source}

National Cancer Institute. General Transcription Factor IIH Subunit 2. NCI Thesaurus. Code C89758.

General transcription factor IIH subunit 2 (395 aa, $\sim 44 \mathrm{kDa}$ ) is encoded by the human GTF2H2 gene. This protein plays a role in both nucleotide excision repair and mRNA synthesis. 